\title{
PENGARUH JENIS KELAMIN DALAM VARIASI INDEKS PRESTASI KUMULATIF MAHASISWA KEDOKTERAN DI UNIVERSITAS PEMBANGUNAN NASIONAL VETERAN JAKARTA
}

\author{
Feda Makkiyah $^{1}$, Erna Harfiani ${ }^{1}$, Anisah ${ }^{1}$ \\ ${ }^{1}$ Fakultas Kedokteran, Universitas Pembangunan Nasional Veteran Jakarta \\ Email : fedamakkiyah@gmail.com
}

\begin{abstract}
ABSTRAK
Banyaknya mahasiswa perempuan dari laki yang memasuki fakultas kedokteran di Indonesia terutama di FK UPNVJ membuat pentingnya perbedaan gender diidentifikasi dan dieliminasi dari metode evaluasi mahasiswa. Studi ini mengeksplorasi perbedaan Indeks Prestasi Kumulatif dalam enam semester mahasiswa kedokteran dan juga menunjukkan topik yang dianggap sulit dalam kedokteran. Studi ini juga sebagai studi awal evaluasi jangka panjang dari proses pendidikan kedokteran. Metode: Studi kohort deskriptif ini mengeksplorasi skor IPK mahasiswa kedokteran tahun 2015 yang telah menjalani 6 semester. Data dianalisis untuk distribusi normal dan studi non parametrik digunakan sebagai langkah terakhir untuk menganalisis korelasi antara jenis kelamin dan kinerja mahasiswa kedokteran dalam 6 semester. Hasil. Skor IPK tertinggi di semester pertama $(3,2)$ dan skor IPK terendah di semester enam (laki-laki, perempuan:2,7; 2,9). Setelah semester pertama, skor turun di semester kedua dan naik lagi di semester 3 dan 4. Skor kemudian menurun ke titik terendah di semester 5 dan 6. Penelitian ini juga menunjukkan tidak ada perbedaan jenis kelamin pada variasi IPK dalam enam semester (P 0,113) dan siswa perempuan memiliki skor IPK lebih tinggi dari siswa lakilaki di semua enam semester. Kesimpulan. Tidak ada perbedaan jenis kelamin dalam Indeks Prestasi Kumulatif dalam enam semester mahasiswa kedokteran di Universitas Pembangunan Nasional Veteran Jakarta dan semester 5 dan 6 adalah semester dengan IPK rendah.
\end{abstract}

Kata kunci: variasi, IPK, mahasiswa kedokteran, jenis kelamin

\begin{abstract}
The number of female medical students outweigh the number of male students in Indonesia and also in school of medicine universitas Pembangunan Nasional Veteran Jakarta has raised the awareness of identification of role of gender in student learning and student assessment. This study explored the differences of Grade Point of Average in six semesters of medical students based on gender and showed the difficult topics in learning medicine. This study was also as a preliminary study of long term evaluation of medical education process. Methods: This descriptive cohort study explored the GPA scores of medical students of year 2015 that have undergone 6 semesters. The data was analyzed for normal distribution and non parametric study was used as final step to analyze the correlation between gender and performance of medical students in 6 semesters. Result. The highest GPA score was in first semester and the lowest GPA score is in the sixth semester. After first semester, the score steps down in second semester and climbed up again in semester 3 and 4 . The score then decrease to the lowest point in semester 5 and 6 . This study also showed there was no significant gender difference of variation of GPA in six semester $(P 0,113)$ and female students have higher GPA scores than male students in all six semester. Conclusion. There was no gender difference in Grade of Point Average score in six semester of medical students in Universitas Pembangunan Nasional Veteran Jakarta and semester 5 and 6 were semester that students have low GPA.
\end{abstract}

Keywords : variation, GPA, medical students, gender 


\section{PENDAHULUAN}

Banyaknya mahasiswa perempuan dari laki yang memasuki fakultas kedokteran di Indonesia terutama di FK UPNVJ membuat pentingnya perbedaan gender diidentifikasi dan dieliminasi dari metode evaluasi mahasiswa. Jenis kelamin adalah salah satu faktor yang juga disebutkan dalam literatur untuk memiliki efek yang cukup besar pada prestasi akademik siswa terutama dalam sains seperti kedokteran. Instimh utama pria adalah berburu dengan spesialisasi belahan otak kanan, bertanggung jawab untuk keterampilan ruang-visual dan matematika. Sebaliknya, belahan otak kiri lebih banyak berkembang pada wanita, yang bertanggung jawab atas keterampilan verbal dan persepsi. Spesialisasi otak wanita ini sesuai dengan perannya sebagai seorang ibu. Argumen ini digunakan sebagai pendukung pendekatan biologis untuk menjelaskan kinerja akademik anak laki-laki yang lebih baik dalam matematika, geometri, dan pelajaran teknis dan perempuan dalam bahasa dan mata pelajaran kemanusiaan lainnya. ${ }^{1}$

Penilaian dalam pendidikan adalah proses untuk menerapkan standar pengukuran dari berbagai tingkat pencapaian atau prestasi pada mata pelajaran. Program Sarjana menggunakan Indeks Prestasi Kumulatif (IPK) digunakan sebagai alat untuk mengukur kinerja siswa. ${ }^{2}$ Selama dekade terakhir ini, lebih banyak siswa perempuan daripada siswa laki-laki yang masuk ke sekolah kedokteran di Indonesia. Sayangnya, tidak banyak penelitian yang dilakukan untuk mengeksplorasi keunggulan dan kekurangan banyaknya jumlah siswa perempuan di sekolah kedokteran di

Setelah semester satu, kedua skor IPK turun ke level yang rendah di semester
Indonesia. Oleh karena itu, penelitian ini bertujuan untuk meneliti apakah ada perbedaan jenis kelamin dalam prestasi mahasiswa kedokteran. Diharapkan penelitian ini bisa menjadi dasar dalam melakukan pendekatan pendekatan proses belajar di Fakultas Kedokteran di Indonesia, khususnya Universitas Pembangunan Nasional Veteran Jakarta.

\section{METODE}

Sampel penelitian kohort deskriptif ini dikumpulkan dari sistem komputerisasi pendidikan universitas Fakultas Kedokteran Universitas Pembangunan Nasional Veteran Jakarta (FK UPN Veteran Jakarta) SIAMAK. Penelitian ini telah mendapatkan persetujuan etik oleh komisi etik FK UPN Veteran Jakarta. Skor IPK mahasiswa kedokteran angkatan 2015 $(n=162)$ dikumpulkan dan dikategorikan berdasarkan jenis kelamin. Saat penelitian dilakukan mahasiswa tersebut telah menjalani pendidikan selama enam semester. Data dianalisis dengan SPSS versi 22. Data ditabulasi dan dianalisis menggunakan model general linier. Besarnya hubungan yang signifikan disajikan sebagai nilai-P $<0,05$ dianggap perbedaan bermakna.

\section{HASIL PENELITIAN}

IPK 162 mahasiswa kedokteran angkatan 2015 telah dikumpulkan. 54 siswa adalah laki-laki dan 108 siswa adalah perempuan. Siswa perempuan lebih banyak daripada siswa laki-laki. Semester pertama rata-rata IPK tertinggi oleh siswa perempuan dan laki-laki $(3,2)$ dan yang menarik IPK terendah adalah keduanya di semester keenam (2,9 dan 2,7; skor IPK). dua (2,9 dan 2,8), namun, kedua skor naik ke puncak pertama di semester tiga. 
Perbedaan utama ditunjukkan pada semester 4, skor IPK siswa perempuan naik ke semester 5 dan secara bertahap turun ke tingkat terendah di semester 6 . Sebaliknya, skor IPK siswa laki-laki turun secara bertahap ke tingkat terendah di semester 6. Nilai menarik lainnya adalah nilai IPK siswa perempuan selalu di atas siswa laki-laki di semester satu sampai semester 6. Tabel 1 menunjukkan rata-rata IPK semester 1 sampai 6 baik laki-laki maupun perempuan $(n=162)$. Semester 1 dengan IPK paling tinggi dan IPK rendah di semester 5 dan 6. Variasi IPK antara perempuan dan laki-laki tidak berbeda secara signifikan $(\mathrm{P}=0,113)$. IPK semester 4 P 0,065 hampir mendekati signifikan $\mathrm{P}<0,05$.

Tabel 1. Rata-rata IPK Semester 1-6

\begin{tabular}{|c|c|c|c|c|c|}
\hline & & Mean & SD & $\mathrm{N}$ & \\
\hline \multirow{2}{*}{$\begin{array}{l}\text { IPK } \\
\text { semester } 1\end{array}$} & Laki & 3.2250 & .34711 & 54 & \multirow[t]{12}{*}{$\mathrm{P} 0,113$} \\
\hline & Perempuan & 3.2490 & .56895 & 108 & \\
\hline \multirow{2}{*}{$\begin{array}{l}\text { IPK } \\
\text { semester } 2\end{array}$} & Laki & 2.8644 & .49646 & 54 & \\
\hline & Perempuan & 2.9934 & .64651 & 108 & \\
\hline \multirow{2}{*}{$\begin{array}{l}\text { IPK } \\
\text { semester } 3\end{array}$} & Laki & 2.9481 & .65220 & 54 & \\
\hline & Perempuan & 3.1213 & .67628 & 108 & \\
\hline \multirow{2}{*}{$\begin{array}{l}\text { IPK } \\
\text { semester } 4\end{array}$} & Laki & 2.9200 & .84300 & 54 & \\
\hline & Perempuan & 3.1580 & .72874 & 108 & \\
\hline \multirow{2}{*}{$\begin{array}{l}\text { IPK } \\
\text { semester } 5\end{array}$} & Laki & 2.8704 & .83982 & 54 & \\
\hline & Perempuan & 3.0639 & .69634 & 108 & \\
\hline \multirow{2}{*}{$\begin{array}{l}\text { IPK } \\
\text { semester } 6\end{array}$} & Laki & 2.7226 & .90749 & 54 & \\
\hline & Perempuan & 2.9620 & .71126 & 108 & \\
\hline
\end{tabular}

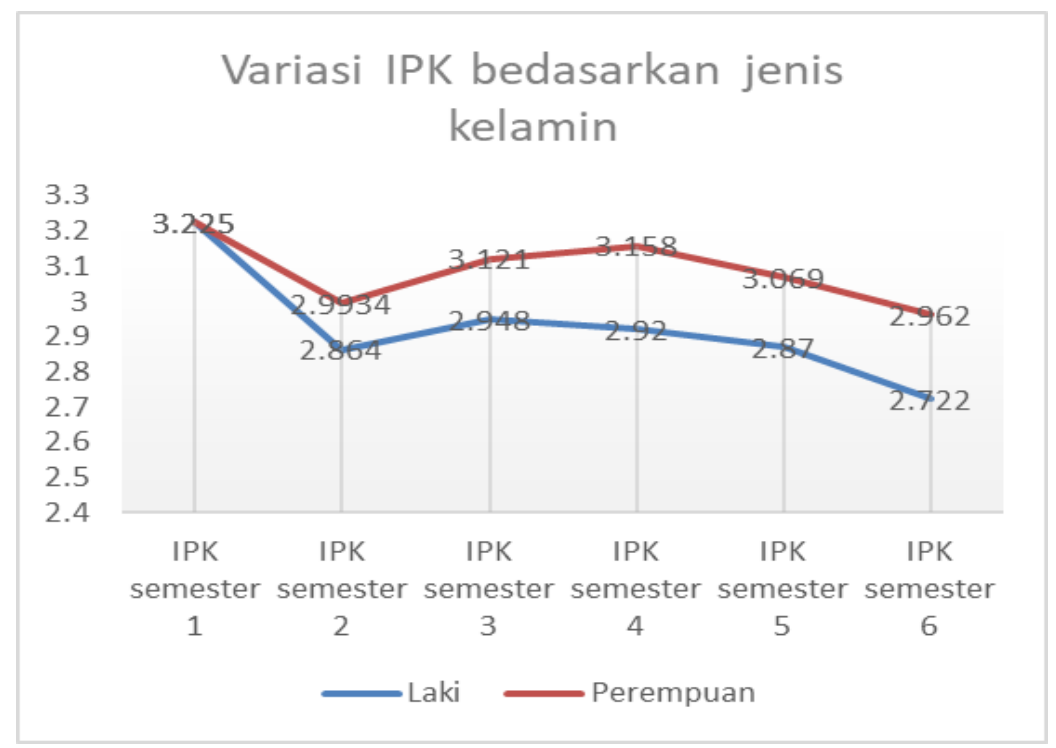

\section{Gambar 1. Rata-rata IPK.}

IPK yang tersebar dari semester 1 sampai dengan semester 6. Pada IPK semester 4, siswa perempuan mencapai titik puncaknya, sebaliknya IPK siswa laki-laki turun ke titik terendah di semester 6 . 


\section{PEMBAHASAN}

Program studi Sarjana Fakultas Kedokteran Universitas Pembangunan Nasional Veteran Jakarta menggunakan sistem blok yang merupakan pengejawantahan sistem Problem Based Learning. Sistem PBL ini terdiri dari kegiatan diskusi tutorial, skill lab (mempelajari suatu prosedur pemeriksaan) atau laboratorium dan kuliah. Porsi terbesar adalah kegiatan tutorial. Kegiatan ini menuntut mahasiswa aktif dalam mempelajari dan menganalisis masalah yang diberikan dalam diskusi tutorial ${ }^{(3,4)}$. Kegiatan yang monoton inilah yang membutuhkan ketekunan dari mahasiswa kedokteran.

Berdasarkan hasil penelitian yang dilakukan, tidak ada perbedaan signifikan jenis kelamin pada variasi IPK dalam enam semester tetapi siswa perempuan memiliki skor IPK lebih tinggi dari siswa laki-laki di semua ke-enam semester. Hal ini bisa dijelaskan bahwa motivasi belajar mahasiswa laki dan perempuan berbeda. Mahasiswa laki-laki belajar karena motivasi luar (status, tes sumatif, income yang diharapkan), sedangkan mahasiswa perempuan lebih mempunya motivasi internal, yang menandakan mereka lebih tertarik dan sangat ingin tahu untuk belajar terhadap topiknya ${ }^{(5,6)}$. Penelitian yang dilakukan pada tahun 1978 yang membandingkan performa dari mahasiswa laki dan perempuan pada program profesi kedokteran. Data dikoleksi dari ujian dari tiga bulan periode rotasi di rumah sakit yang meliputi 269 mahasiswa kedokteran, 222 laki dan 47 wanita selama tahun 1975 dan 1976. Penelitian tersebut menyimpulkan tidak ada perbedaan yang bermakna dari hasil ujian kedua gender. Performa di ruangan atau poliklinik pada ujian tulis atau interview juga menyimpulkan tidak ada perbedaan yang bermakna. $^{7}$

Semester 1 mahasiswa kedokteran Fakultas Kedokteran Universitas Pembangunan Nasional Veteran Jakarta mempelajari blok Fundamental Basic Science (FBS) 1 dan 2 yang merupakan topik yang mempelajari hal hal yang dasar mengenai tubuh manusia. Semester 2 mahasiswa mempelajari blok Dermatomusculoskeletal System dan Special Sensory System. Mahasiswa akan belajar mengenai kelainan kulit, otot, mata, telinga dan hidung. Semester 3 dimulai dengan pembelajaran blok kardiovaskular sistem dan hematoimunologi sistem. Semester 3 ini mulai dengan topik yang lebih berat dan semester 4 dilanjutkan dengan blok Gastrointestinal System dan Endocrine Metabolic System. Semester 5 dimulai dengan blok Neurobehaviour System dan Genitourinary System. Semester 6 dengan blok Respiratory System dan Reproductive System. Kalau dari grafik di atas bisa dilihat bahwa IPK paling tinggi ada di semester 1 dengan topik pembelajaran FBS yang masih sama dengan topik di sekolah menengah atas dan mahasiswa masih semangat di semester awal kuliah.

Pada saat mahasiswa masuk pada semester 2 dengan topik yang sudah lebih mendalam ke arah penyakit dan membutuhkan analisis lebih dalam IPK laki dan perempuan turun. Semester 3 kembali naik meski tidak setinggi IPK di semester 1. Akan tetapi mahasiswa perempuan tetap menanjak pada semester 4 sedangkan mahasiswa laki-laki turun secara gradual sampai di semester 6 . Mahasiswa perempuan juga setelah semester 4, turun secara gradual sampai titik terendah di semester 6. Semester 5 pembelajaran dimulai dengan blok 
Neurobehaviour System dan Genitourinary System. Semester 6 mereka mulai dengan menulis skripsi yang memungkinkan IPK yang lebih menurun karena konsentrasi terpecah.

Persepsi mahasiswa tentang topik yang sulit pada mahasiswa kedokteran seperti blok Neurobehaviour System, hal yang senada juga dijumpai pada penelitian yang meneliti tentang topik anatomi yang dianggap sulit oleh mahasiswa kedokteran. Penelitian tersebut menyimpulkan bahwa anatomi saraf, kepala dan leher dianggap yang paling sulit oleh mahasiswa kedokteran. ${ }^{4,8}$ Penelitian pada mahasiswa FK UPNVJ pada semester 5 kedua jenis kelamin mulai mengalami penurunan IPK, yaitu perkuliahan dengan blok Neurobehaviour System. Jadi, sesuai dengan penelitian sebelumnya, blok

\section{DAFTAR PUSTAKA}

1. Guledani K. Gender Influence on Educational Process. https://www.gwiboell.de/en/2011/02/08/genderinfluence-educational-process

2. Richardson M., Abraham C., \& Bond R. Psychological Correlates of University Students' Academic Performance: A Systematic Review and Meta-analysis. Psychological Bulletin. 2012; 138 (2): 353.

3. Kaufman D.M.J.B. Applying Educational Theory in Practice. BMJ. 2003; 326 (7382): 213-216.

4. Schattner A. Curiosity. Are You Curious Enough to Read On? London: SAGE Publications Sage; 2015.

5. Bekkink M.O., Donders A.R., Kooloos J.G., de Waal R.M., Ruiter D.J. Challenging Students To Formulate Written Questions: A Randomized Controlled Trial To Assess Learning mengenai saraf merupakan blok sulit buat mahasiswa.

Kelemahan penelitian ini adalah tidak meneliti faktor faktor yang mempengaruhi IPK yang berbeda menurut jenis kelamin. Saran untuk penelitian di kemudian hari agar mengkorelasikan, IPK, jenis kelamin, cara belajar, topik sehingga issue jenis kelamin pada pendidikan fakultas kedokteran bukan membuat menjadi perbedaan akan tetapi terbentuknya pendekatan pembelajaran yang sesuai dengan jenis kelamin.

\section{KESIMPULAN}

Terdapat perbedaan yang tidak signifikan antara Indeks Prestasi Kumulatif antara laki dan perempuan dan semester 5 dan 6 adalah semester dengan IPK terendah.

Effects. BMC Medical Education. 2015;15(1):56.

6. Kusurkar R, Kruitwagen C, ten Cate O, Croiset G. Effects of age, gender and educational background on strength of motivation for medical school. $A d v$ Health Sci Educ Theory Pract. 2010; 15 (3): 303-313.

7. Holmes F.F., Holmes G.E., \& Hassanein R. Performance of Male and Female Medical Students in A Medicine Clerkship. JAMA. 1978; 239 (21): 2259-2262.

8. Hall S., Stephens J., Parton W., Myers M., Harrison C., Elmansouri A., et al. Identifying medical student perceptions on the difficulty of learning different topics of the undergraduate anatomy curriculum. Med.Sci.Educ. 2018; 28 (3): 469-472. 